\title{
Modeling Microbial Transport in Porous Media: Traditional Approaches and Recent Developments
}

\author{
Advances in Water Resources \\ Special Issue: Biological Processes in Porous Media
}

Revised: May 5, 2006

NATHALIE TUFENKJI

Department of Chemical Engineering, McGill University, Montreal, Quebec H3A 2B2, Canada

*Phone: (514) 398-2999; Fax: (514) 398-6678; E-mail: nathalie.tufenkji@mcgill.ca 


\begin{abstract}
A substantial research effort has been aimed at elucidating the role of various physical, chemical and biological factors on microbial transport and removal in natural subsurface environments. The major motivation of such studies is an enhanced mechanistic understanding of these processes for development of improved mathematical models of microbial transport and fate. In this review, traditional modeling approaches used to predict the migration and removal of microorganisms (e.g., viruses, bacteria, and protozoa) in saturated porous media are systematically evaluated. A number of these methods have inherent weaknesses or inconsistencies which are often overlooked or misunderstood in actual application. Some limitations of modeling methods reviewed here include the inappropriate use of the equilibrium adsorption approach, the observed breakdown of classical filtration theory, the inability of existing theories to predict microbial attachment rates, and omission of physical straining and microbe detachment. These and other issues are considered with an emphasis on current research developments. Finally, recently proposed improvements to the most commonly used filtration model are discussed, with particular consideration of straining and microbe motility.
\end{abstract}




\section{Introduction}

There is a considerable ongoing effort aimed at understanding the transport and deposition behavior of microorganisms in saturated porous media. A mechanistic understanding of these processes is of significant interest in various environmental applications such as in-situ bioremediation [125], riverbank filtration [136], and protection of drinking water supplies [45].

Certain indigenous microbes present in the subsurface can enhance the mobility of radionuclides, metals and other toxic contaminants. The natural degradative capabilities of native strains may be exploited in the application of biostimulation strategies targeting restoration of contaminated aquifers. Successful use of such remediation technologies and risk assessment of microbe-facilitated pollutant transport requires a means to predict the transport potential of microorganisms. An improved understanding of the factors controlling the fate and transport of microbes in porous media is also important in the design and function of engineered in-situ bioremediation schemes involving introduction of large volumes or high concentrations of bacteria (e.g., in the use of a biobarrier or in bioaugmentation) [125]. In such cases, the common objective is to achieve a target microbe concentration at a specific location.

Widespread microbial contamination of drinking water supplies has further prompted the need to better predict the transport behavior of microbes in the subsurface. Viruses, protozoa (e.g., Cryptosporidium parvum) and certain bacteria are pathogens of concern which may be introduced into the natural environment from land disposal of treated wastewater effluents or animal fecal deposits $[81,123,143]$.

Microbial transport and deposition in porous media has traditionally been studied in experiments using bench-scale packed columns, where the suspended effluent microbe concentration is monitored as a function of time. One of the first studies of this type was reported 
by Bales et al [4], where the transport of the bacteriophage $\mathrm{f} 2$ and MS-2 was investigated using columns packed with sandy soil and fractured rock. Since, a great deal of research has been conducted in the laboratory [57] and in the field $[38,58,60,70,117,145]$ in an attempt to elucidate the factors controlling the transport and fate of microorganisms in porous media.

Packed column experiments have been used to assess the influence of biological factors such as cell surface macromolecule length and composition $[2,105,141,144]$, cell motility [11, $24,26,83]$, cell size and shape $[11,46]$, organism type $[35,62,64,104,118]$, and growth phase $[122,140]$ on bacterial transport and deposition kinetics in porous media. Other physical and chemical conditions which have been evaluated include grain size $[46,64,78,118]$ and shape [20], presence of surface coatings on collector media $[11,13,47,118]$, fluid velocity $[11,24,49,62$, 104, 127], solution ionic strength and composition [13, 37, 46, 49, 64, 78, 79, 103, 105, 119], and cell concentration [24, 25, 127]. In studies of virus fate and transport, bacteriophages are often used as model particles $[61,114]$. The removal of viruses in granular filtration has been examined using packed beds of quartz sand [28, 68, 91, 100-102], glass beads [5, 6], and natural sediments $[4,41,72,75,115]$. In general, viral attachment kinetics seem to be controlled by electrostatic interactions $[91,102,114]$. In comparison to bacteria and viruses, well-controlled laboratory studies on the removal mechanisms of protozoan (oo)cysts in flow through saturated porous media are relatively scarce. The limited body of literature on this subject is focused on the filtration behavior of Cryptosporidium parvum [1, 21, 33, 54, 65, 82, 133, 134] and Giardia lamblia [65] — two waterborne pathogens of considerable concern $[81,143]$. Specifically, the role of solution ionic strength and composition $[33,65,133,134]$, grain size and shape $[21,54,82,134]$, fluid velocity [54], and collector surface heterogeneity [1] has been examined. 
Although well-defined laboratory experiments provide an improved understanding of the fundamental mechanisms controlling microbial transport and deposition, the results of these studies are often not directly relevant to processes occurring in natural and engineered systems. The inherent physical, chemical and biological heterogeneity of such systems presents a highly complex environment to mimic [50]. Field-scale observations and experiments offer a practical compromise, however the results of these studies are often difficult to generalize. The role of physical heterogeneity in controlling bacterial transport through aquifer sediments has been demonstrated at two research locations - the US Geological Survey's Cape Cod Site, MA [59], and the Narrow Channel area of the South Oyster Site, VA [38, 66, 70]. Several field-scale studies have been used to assess the influence of chemical heterogeneities of grain (collector) surfaces, such as iron oxide $[110,117]$ and organic matter coatings $[93,110,116]$, as well as the effect of aquifer media physical heterogeneity $[86,87,94,145]$ on virus transport and fate. In contrast, few investigations have been conducted to examine the removal of protozoan (oo)cysts at the fieldscale $[58,60]$.

Typically, in such laboratory and field-scale studies, microbial transport and deposition kinetics are evaluated by measuring the suspended (fluid-phase) microbe concentration at a given travel distance. These findings may subsequently be utilized in the development of predictive models for microbial transport behavior in natural and engineered aquatic systems. However, recent theoretical [135] and experimental $[10,76-78,130,132]$ investigations suggest that monitoring fluid-phase particle concentration is inadequate in identifying the fundamental mechanisms controlling particle (or microbe) transport. Rather, it has been shown that the spatial distribution of retained microorganisms, in addition to fluid-phase concentrations, provides a more 
accurate characterization of transport and deposition behavior in saturated porous media [76, 77, $130,132,135]$.

Mathematical models of microbial transport in saturated porous media generally involve a simplified form of the advection-dispersion equation, which can be derived from basic mass balance principles. In the most commonly used modeling approach, microbe removal is considered to be governed solely by attachment to sediment grain surfaces. Indeed, few modeling efforts take into account the influence of the numerous physical, chemical and biological factors which are known to affect microbe transport and fate in the subsurface [148]. The factors and mechanisms which influence microbial transport and removal in saturated porous media have been reviewed extensively $[45,55,126,148]$, however their incorporation into predictive models remains a challenge.

The purpose of this paper is to critically review traditional approaches used to model microbial transport and fate in saturated porous media. In the first section, the general governing equations typically considered in models of microbial transport and fate are presented. Next, the limitations associated to application of these mathematical models are reviewed; for instance, the inadequacy of the equilibrium adsorption approach, the difficulties in the prediction of microbial deposition rates and the relevance of straining for larger microorganisms. Finally, recently proposed initiatives which may improve the predictive capabilities of transport models are discussed.

\section{Traditional Approaches to Predicting Microbial Transport and Fate}

Several mechanisms act independently or simultaneously to control the movement and fate of microorganisms in natural and engineered aqueous systems. These processes can be classified 
into three major groups: (i) transport, (ii) exchange between the liquid phase and the solid phase (due to attachment and detachment), and (iii) inactivation, grazing or death [128]. In modeling the transport and fate of microorganisms in porous media, the appropriate mathematical descriptions for these processes must be considered.

\subsection{The general advection-dispersion equation}

At the macroscopic level, the temporal and spatial variations of microbe concentration in a homogeneous, water-saturated porous medium are described by the advection-dispersion equation (shown here in a single spatial dimension for simplicity) [114, 148]:

$$
\frac{\partial C}{\partial t}=D \frac{\partial^{2} C}{\partial x^{2}}-v \frac{\partial C}{\partial x}
$$

where $C$ is the microbe concentration in the aqueous phase at a distance $x$ and time $t, D$ is the hydrodynamic dispersion coefficient, and $v$ is the interstitial microbe velocity.

In eq 1 , only the physical transport processes of advection and hydrodynamic dispersion are considered. As microorganisms are transported through porous media, they are removed from the pore fluid by physicochemical filtration (attachment to sediment grain surfaces). Physicochemical filtration has been modeled as either an irreversible (no detachment) or reversible process. In the case of reversible attachment, both equilibrium and kinetic mechanisms have been applied [148]. Regardless of the type of attachment mechanism used to describe removal of microbes from the pore fluid, the governing equation for microbial transport and fate in a onedimensional, homogeneous, saturated porous medium becomes $[114,148]$ :

$$
\frac{\partial C}{\partial t}+\frac{\rho_{b}}{\varepsilon} \frac{\partial S}{\partial t}=D \frac{\partial^{2} C}{\partial x^{2}}-v \frac{\partial C}{\partial x}
$$


where $S$ is the attached microbe concentration, $\rho_{\mathrm{b}}$ is the dry bulk density of the porous medium, and $\varepsilon$ is the bed porosity.

\subsection{Equilibrium "adsorption" of microbes}

Both Langmuir and Freundlich isotherms have been used to describe the so-called equilibrium "adsorption" of microbes to solid surfaces [148]. For the special case of a linear adsorption isotherm, $S=K_{\mathrm{eq}} C$. In this case, eq 2 can be rewritten as [114, 148]:

$$
R \frac{\partial C}{\partial t}=D \frac{\partial^{2} C}{\partial x^{2}}-v \frac{\partial C}{\partial x}
$$

where $R=1+\rho_{\mathrm{b}} K_{\mathrm{eq}} / \varepsilon$ is commonly referred to as the retardation factor.

\subsection{Kinetic attachment and detachment processes}

In a suspension of microbes and sediment grains, an equilibrium adsorption state is not reached instantaneously [114]. Rather, a kinetic attachment mechanism which is composed of two processes controls the removal of microorganisms from the aqueous phase. In the first step, described as mass transport, microbes are transferred from the bulk fluid to the surface of the sediment grains. In the second step, microbes are attached to the surface as a result of physicochemical interactions $[15,114,148]$. The subsequent release (detachment) of microorganisms may also be controlled by a kinetic process. Under these conditions, the rate of change in retained microbe concentration can be described as follows:

$$
\frac{\rho_{b}}{\varepsilon} \frac{\partial S}{\partial t}=k_{a t t} C-\frac{\rho_{b}}{\varepsilon} k_{\mathrm{det}} S
$$

where $k_{\text {att }}$ and $k_{\text {det }}$ are the microbial attachment and detachment rate coefficients, respectively. It should be noted that the processes described by eqs 3 and 4 neglect the effects of microbial growth 
as well as microbe-microbe interactions which may occur under certain conditions (e.g., blocking, ripening and/or aggregation in the aqueous phase) $[25,44]$.

\subsection{Irreversible attachment under "clean-bed" conditions}

The most commonly used approach for evaluating microbial transport behavior in laboratory and field-scale studies is the classical colloid filtration theory (CFT) [56, 109, 114, 146]. In effect, this "clean-bed" filtration model is a special case of the general formulation described in section 2.3 , whereby the attachment of microbes to sediment surfaces is considered irreversible, i.e., negligible release of microorganisms [135]. In the CFT, the mass transport process is reflected in the single-collector contact efficiency, $\eta_{0}$, and the surface attachment step is described by the attachment (collision) efficiency, $\alpha[44,146]$. This model is relevant to most applications of practical interest, where the system may be considered at steady-state and initially free of microorganisms, and the influence of hydrodynamic dispersion is negligible (i.e., the dispersion term is small compared to the advection term, or the Peclet number $\left(N_{\mathrm{Pe}}=v x / D\right)$ is greater than about 5 [137]). Under these conditions, for a continuous particle injection at concentration $C_{0}($ at $x=0)$ and time period $t_{0}$, the solutions to eqs 2 and 4 are [135]:

$$
\begin{gathered}
C(x)=C_{0} \exp \left[-\frac{k_{a t t}}{v} x\right] \\
S(x)=\frac{t_{0} \varepsilon k_{a t t} C_{0}}{\rho_{b}} \exp \left[-\frac{k_{a t t}}{v} x\right]
\end{gathered}
$$

where the microbe attachment rate coefficient is related to $\eta_{0}$ and $\alpha$ via

$$
k_{a t t}=\frac{3(1-\varepsilon) v}{2 d_{c}} \eta_{0} \alpha
$$

Here, $d_{\mathrm{c}}$ is the average grain size. In the case of soil grains that may not be spherical or uniform in shape, the average grain size can be characterized by the arithmetic mean diameter $\left(d_{\mathrm{a}}\right)$, the 
geometric mean diameter $\left(d_{\mathrm{g}}\right)$, or the diameter for which $10 \%$ of all particles in the volume distribution are smaller $\left(d_{10}\right)$ [78]. Since current theories are inadequate for predicting the attachment efficiency [44], it is common to use measurements of the normalized suspended microbe concentration $\left(C / C_{0}\right)$ at a packed length $x$ to determine $\alpha$ values for a given system. In this case, the theoretical value of the single-collector contact efficiency $\left(\eta_{0}\right)$ may be determined numerically or using a closed-form equation $[98,131,146]$.

\subsection{Microbe inactivation or die-off}

Inactivation or death is the second major mechanism which governs the removal of microbes during transport in porous media. This irreversible sink mechanism may affect both suspended or attached microorganisms and is commonly described by a first-order rate expression $[32,148]$. In saturated natural environments, microbe inactivation may be affected by solution composition and $\mathrm{pH}$, temperature, grazing, and attachment to sediment surfaces. However, the effect of these variables on the rate of inactivation is not clear [148]. It has been reported that temperature is the most important factor that influences virus inactivation, and some researchers have proposed formulations to describe the temperature dependence of the virus inactivation rate $[114,148]$. These studies suggest that the virus inactivation rate is an exponential function of the porewater temperature $[114,148]$.

\section{Limitations of Existing Modeling Approaches}

Several different methods to model microbe transport and fate in saturated porous media have been employed. As described previously, these mathematical models generally differ in the description of fundamental microbe removal mechanisms. Thus, it follows that certain approaches 
may have inherent weaknesses or inconsistencies which should be addressed. In this section, the limitations of existing modeling approaches and their implications are discussed.

\subsection{The equilibrium adsorption mechanism may be inadequate}

Attachment of microorganisms by a so-called equilibrium "adsorption" mechanism has been considered in both laboratory $[5,27,28,41,54,68,90,95,99]$ and field-scale investigations $[8,56,96,121]$. It should be noted though that equilibrium adsorption does not result in removal of microbes from the aqueous phase [114]. Rather, this process gives rise to retarded breakthrough of microorganisms in comparison to that of a conservative (inert) tracer, i.e., it is completely reversible. The retardation factor, $R$, is a direct measure of this delayed breakthrough, where an $R$ value equal to one indicates no retardation. However, only a few laboratory studies of virus [5, $41,90,95]$ and bacteria [27] transport have reported retardation factors greater than one. In most controlled packed-column experiments where the transport of viruses $[5,6,28,68,72]$, bacteria $[35,38,40,46,62,63,103,104,119,120,141]$ or protozoa $[54,134]$ has been examined, the observed breakthrough has been comparable to that of a tracer. Similarly, little or no retardation has been reported in several tank and field-scale investigations of microbial transport $[7,8,34,56$, $93,110,116,118,121]$.

Bales et al $[5,8]$ investigated the transport and removal of different bacteriophages in both laboratory and field-scale experiments. In these studies, the influence of equilibrium adsorption on the attachment of viruses to collector surfaces was found to be negligible. Instead, virus attachment was shown to be controlled by a kinetic process which is reflected in the slow-rising limbs and long tails of the measured breakthrough curves. A representative breakthrough curve measured with bacteriophage PRD-1 in a column packed with silica beads at $\mathrm{pH} 5.5$ is presented in Figure 1a. This result clearly demonstrates the strong kinetic effect observed by Bales et al [5]. 
A typical breakthrough curve measured in a field study by Schijven et al [116] for bacteriophage MS-2 is shown in Figure 1b. Comparison of MS-2 transport behavior (open symbols) with that of a salt tracer (solid line) indicates that phage transport was not retarded by equilibrium adsorption. The slowly rising limb and significant tailing observed in the virus breakthrough curve reveal that virus transport was governed mainly by a kinetic process. Schijven and Hassanizadeh [114] described numerical results which show that predictions of microbial transport by an equilibrium approach and a kinetic approach may sometimes lead to similar conclusions. Their calculations illustrate how an investigation of tailing is required to distinguish between the two mechanisms. Reddy and Ford [99] further demonstrated how measurements of the microbe spatial distribution may be necessary to identify which of the two modeling approaches is more accurate.

\section{[FIGURE 1]}

As described above, equilibrium adsorption does not contribute to the removal of microbes from the pore space. Hence, in using this modeling approach to describe microbe attachment, actual removal of microbes may be accounted for only by including an inactivation (die-off) term and/or an additional sink term for attachment [114]. Some researchers have considered a microbial transport model which combines an equilibrium adsorption process with a first-order irreversible attachment mechanism (described in section 2.4) $[27,56]$. In these studies, the microbial deposition rate coefficient $\left(k_{\text {att }}\right)$ is defined within the context of colloid filtration theory. However, there is considerable evidence in the microbe transport literature that the contribution of equilibrium adsorption to microbe attachment is generally negligible and therefore this approach may be inappropriate for most situations. Obviously, significant errors can arise from application of an equilibrium sorption model to nonequilibrium conditions [5]. As a result, colloid filtration 
theory (eq 5) has been used extensively to evaluate microbial transport and fate in saturated porous media $[2,6,19,24,34,37,79,91,93,100,101,103,104,134,141]$.

\subsection{Colloid filtration theory is not valid under unfavorable (repulsive) conditions}

Traditionally, microbe attachment kinetics have been assessed using measurements of the fluid-phase microbe concentration. A theoretical evaluation of the factors controlling the transport and fate of microorganisms in laboratory-scale column experiments reveals that the spatial distribution of retained microbes is a more sensitive measure of filtration behavior than the profile of suspended microbes [135]. Furthermore, recent studies suggest that filtration of microorganisms may not be consistent with CFT [3, 10, 14, 24, 78, 100, 101, 133]. The most reliable method to assess the validity of CFT is to compare the measured spatial distribution of retained particles to that predicted based on the measured breakthrough curve.

Column experiments have been conducted under well-controlled physicochemical conditions using uniform spherical latex particles and glass bead collectors, where both the effluent fluid-phase concentration and the spatial distribution of retained particles have been examined $[76,77,130,132]$. Results of these studies indicate that particle deposition behavior is in good agreement with CFT (eqs 5-7) under conditions which are favorable for deposition (i.e., in the absence of repulsive electrostatic interactions) (Figure 2a, b). However, CFT is generally observed

to break down in the presence of repulsive Derjaguin-Landau-Verwey-Overbeek (DLVO) interactions [36, 139], namely, under conditions deemed unfavorable for particle deposition (Figure 3a, b).

[FIGURE 2]

[FIGURE 3] 
Systematic experimental studies conducted with different-sized colloids over a broad range of physicochemical conditions recently revealed the controlling influence of secondary minimum deposition and surface charge heterogeneities on the observed deviation from colloid filtration theory $[130,132]$. These findings further suggest that it is not necessarily the occurrence of an energy barrier in the particle-collector interaction energy profile that causes breakdown of CFT. Rather, the authors propose a dual deposition mode mechanism, whereby particles which overcome an energy barrier to reach the primary energy minimum deposit at a relatively "slow" rate in comparison to those particles which are retained in the secondary energy minimum or as a result of surface charge heterogeneities (where deposition is unhindered or "fast") [130, 132].

These results have important implications for predictions of microbial transport since the mechanisms identified are common to colloidal interactions in natural and engineered aquatic systems. In particular, since the depth of the secondary energy well is directly proportional to particle size, this mechanism can play an important role in the deposition behavior of larger microorganisms (e.g., bacteria and protozoa) $[103,133]$. In a similar study using oocysts of Cryptosporidium parvum (C. parvum), Tufenkji and Elimelech [133] proposed that oocyst transport was controlled by "slow" deposition in the primary energy well, as well as the two aforementioned mechanisms of "fast" deposition — namely, secondary minimum deposition and retention due to charge heterogeneities. However, classic CFT (eqs 5-7) does not account for the combined effects of "fast" and "slow" oocyst deposition in the presence of repulsive electrostatic interactions. In general, predictions of oocyst removal assessed using CFT are greatly overestimated, thus revealing a significant risk of contamination when CFT is used to establish water treatment guidelines [133]. Other laboratory studies of microbial transport and deposition 
involving viruses $[100,101]$ and bacteria $[10,129]$ also suggest that a model which takes into account a distribution in deposition rates may be better suited for prediction of microbe migration.

\subsection{Determination of the attachment efficiency is complex}

Classic theoretical approaches used to determine particle deposition rates in the presence of repulsive energy barriers include trajectory analysis for non-Brownian particles [98], and numerical solution of the convective-diffusion equation $[44,97]$. In the latter case, an approximate analytical solution to the governing equation - the interaction-force boundary-layer (IFBL) approximation - is commonly utilized $[44,108,124]$. These approaches, which incorporate the DLVO theory, have traditionally failed to predict observed particle deposition rates under unfavorable conditions, even when experiments were conducted in well-controlled model systems $[44,109]$. In general, particle deposition rates (or attachment efficiencies) calculated using these models are many orders of magnitude smaller than those measured experimentally.

An extended DLVO theory has been proposed by Van Oss et al [138] which includes short range Lewis acid-base interactions in microbial adhesion. A limited number of studies have been reported where experimentally-determined microbial deposition rates (using eqs 5 and 7) are compared with those calculated using the abovementioned theoretical approaches (which consider either classic or extended DLVO theory) [10,39]. Most often though, these comparisons evoke the inadequacies of existing models used to calculate $\alpha$; i.e., theoretical deposition rates are much less than measured values. In contrast, predictions of particle [48, 51, 53] and microbe [39] deposition rates which approach experimental results have been obtained by considering a model based on deposition in the secondary minimum. In this simple model, the kinetic theory of Maxwell is used to calculate the theoretical attachment efficiency for deposition in the secondary 
energy well $[51,53]$. Under conditions where repulsive electrostatic double-layer interactions predominate, microbe retention in a secondary energy well seems very likely. The considerable influence of this mechanism on bacterial transport behavior has been demonstrated using complementary experiments in a packed column setup and radial stagnation point flow (RSPF) system $[103,141]$. Because of the design and hydrodynamics of the RSPF system, cells retained in a secondary minimum would be swept away by the radial flow component, allowing only the deposition of cells in a primary energy well [103]. Hence, by comparing the degree of bacterial deposition in the RSPF system to that measured in a traditional packed column experiment, the authors showed that secondary minimum deposition was a controlling factor $[103,141]$. As mentioned previously, the influence of this mechanism on microbial transport has also been demonstrated in experiments using oocysts of C. parvum [133]. In effect, there is a growing body of evidence which suggests that the simple model for calculating $\alpha$ based on deposition in the secondary energy minimum may help improve predictions of microbial transport in porous media $[48,51-53,132]$.

Inspection of eqs 5 and 7 reveals that assessment of the attachment efficiency, $\alpha$, in packedcolumn experiments is dependent on the measured (or calculated) value of the single-collector contact efficiency, $\eta_{0}$. The classic filtration model of Yao et al [146] and the correlation equation of Rajagopolan and Tien [98] have been used extensively to predict values of $\eta_{0}$ for colloids and microorganisms in natural and engineered systems. Recently, a new correlation equation for calculating $\eta_{0}$ which overcomes the inherent limitations of these approaches was presented by Tufenkji and Elimelech [131]. Specifically, this new correlation improves upon earlier models by considering the influence of hydrodynamic (viscous) interactions and van der Waals interactions on the deposition of particles by Brownian diffusion. The resulting improvement in predictions of 
$\eta_{0}$ has direct implications for studies of microbial transport, including viruses, bacteria, and protozoa. For instance, calculations based on the Tufenkji and Elimelech (TE) equation indicate that particles in the size range of $\sim 2 \mu \mathrm{m}$ (e.g., many bacteria) are nearly twice as mobile in porous media than previously believed [131]. Such improvements in calculations of $\eta_{0}$ translate into better predictions of microbial attachment efficiencies $(\alpha)$ when CFT is applied.

\subsection{The influence of cell/cyst surface biomolecules is not well understood}

It is well known that microbial cell/cyst surfaces are both chemically and structurally more complex and heterogeneous than most inorganic particles [15]. This inherent constitutional complexity of microbe surfaces, combined with variability across different strains and species, contribute to the difficulty in generalizing findings regarding the mechanisms of microbial adhesion. Surface biomolecules, which may include proteins, lipopolysaccharides (LPS), and extracellular polysaccharides, can occur in a broad range of sizes, compositions, and conformations. Recent studies have attempted to improve our understanding on the role of such macromolecules in microbial adhesion $[2,22,23,29,30,74,105,107,141,144]$. In general, these findings show that the presence of surface biomolecules can either enhance [2, 22, 105-107, 141] or hinder $[22,74,105-107,144]$ microbe adhesion in aqueous media.

Burks et al [22] and Walker et al [141] used the same three strains of Escherichia coli $(E$. coli) K12 to investigate the role of LPS on microbial transport and attachment. The selected bacteria differed primarily in LPS length and composition. In these studies, bacterial adhesion could not be correlated with LPS length or microbe surface charge [22, 141]. Rather, it was proposed that a combination of DLVO-type interactions and surface macromolecule-associated interactions influence the degree of bacterial adhesion. Using atomic force microscopy (AFM) to 
assess the influence of lipopolysaccharides on the attachment of E. coli K12 mutant JM109, AbuLail and Camesano [2] demonstrated qualitative agreement between measured adhesion forces and cell attachment to glass and quartz surfaces. However, in the same study, measurements of interaction forces upon approach of the AFM tip to the bacterium did not correlate with cell adhesion behavior to glass or quartz sand. Taken together, the results of these studies on bacterial adhesion draw attention to the difficulty in relating microbe and biomolecule characteristics to observed transport and adhesion behavior.

AFM measurements [29-31] and experiments conducted in a RSPF system [74] suggest that surface biomolecules can also affect protozoan adhesion in aqueous systems. Research shows that proteins of the C. parvum oocyst wall can give rise to a steric interaction (repulsion) thereby decreasing the degree of oocyst attachment to quartz surfaces. Considine et al [29-31] studied the force of interaction between $C$. parvum oocysts and silica surfaces over a broad range of physicochemical conditions relevant to granular filtration. The researchers proposed that the observed steric interaction between $C$. parvum and a siliceous material could be attributed to the presence of a "hairy" protein layer extending from the oocyst surface. Kuznar and Elimelech [74] provided further evidence in support of this theory by comparing the deposition behavior of viable oocysts with those of inactivated oocysts (both formalin and heat treated). Low deposition rates are measured with viable (untreated) oocysts even at high salt concentrations when electrostatic energy barriers are eliminated (Figure 4). This behavior is attributed to a steric repulsion between viable $C$. parvum oocysts and the quartz surface. Significant increases in oocyst deposition rates were observed after oocysts were inactivated with formalin or heat. Kuznar and Elimelech [74] linked the increased deposition rates to postulated changes in the structure of oocyst surface proteins caused by formalin and heat treatments. Additional experiments conducted with viable 
C. parvum oocysts further suggest that specific surface interactions between oocyst wall proteins and silica surfaces could retard or even completely inhibit oocyst detachment (release) $[29,31,73$, 133].

\section{[FIGURE 4]}

We are only just beginning to have an understanding of the role of surface biomolecules in bacteria and protozoa transport and fate in saturated porous media. Upon approach of a microorganism to a surface, the presence of macromolecules such as LPS or proteins on cell/(oo)cyst surfaces can give rise to a broad range of interactions. This variability in the influence of biomolecules on microbial adhesion presents a major challenge to the incorporation of related mechanisms in microbe transport models.

\subsection{Physical straining can be important for larger microorganisms}

Predictions of particle straining potential based on system geometry suggest that physical straining could play a significant role when the ratio of the particle diameter to the median grain diameter $\left(d_{\mathrm{p}} / d_{\mathrm{c}}\right)$ is greater than $0.05[112,113]$. However, several experimental studies indicate that straining could be an important mechanism of particle removal during porous media transport when the ratio $d_{\mathrm{p}} / d_{\mathrm{c}}$ is less than 0.05 , and even when it is as low as $0.002[16,18,134]$.

Bradford et al [16-18] examined the influence of colloid size and collector (grain) size on particle transport using columns packed with sand or glass beads. Two approaches were used to simulate particle transport in these systems: (i) a model which considers kinetic attachment and detachment (described by eqs 4 and 7) and (ii) a model which describes the irreversible removal of particles by a straining mechanism. Comparison with experimental results revealed that the straining model was generally in better agreement with measurements of effluent particle 
concentration and spatial distributions of retained particles. These researchers also indicate that a model which considers removal of particles by both attachment and physical straining is more realistic, particularly for systems of intermediate particle and grain sizes.

Indeed, a systematic study of $C$. parvum transport behavior in columns packed with ultrapure quartz sand indicates that both straining and physicochemical filtration (attachment) affect the removal of oocysts from the pore fluid [134]. Experiments conducted in columns packed with glass beads of comparable size to the quartz sand revealed that grain shape contributes considerably to the straining potential of the porous medium. This effect was further examined by considering the transport of latex particles of increasing size in deionized (DI) water (Figure 5). In DI water, the electrostatic double-layer repulsion between particles and collectors is substantial so that physicochemical filtration (attachment) should be negligible. Under these conditions, any removal in the packed column can be attributed to the influence of a physical mechanism such as straining. As shown in Figure 5, the smallest latex particles $(0.32$ and $1.0 \mu \mathrm{m})$ exhibit no removal $\left(C / C_{0} \approx 1\right)$ after passage in the column packed with quartz grains. The degree of removal for the $1.9 \mu \mathrm{m}$ particle is also minor. However, the $4.1 \mu \mathrm{m}$ particle, which is comparable in size to the $C$. parvum oocysts, exhibits significant removal $\left(C / C_{0} \approx 0.63\right)$, indicating that straining can be an important capture mechanism in this type of porous medium. In addition, an observed increase in oocyst deposition rates with solution ionic strength confirmed that physicochemical filtration (attachment) also contributes to the removal of $C$. parvum in saturated porous media, possibly via deposition in a secondary energy minimum.

\section{[FIGURE 5]}

As indicated in Section 2 above, microbial transport in saturated porous media is generally described using classic colloid transport models where particles are assumed to be spherical in 
shape. In reality, however, bacteria are known to exhibit a variety of shapes, including rods, ellipsoids, spirals, and coccoids [142]. Although it has been shown that cell shape can play a role in bacterial transport $[46,142]$, few studies have systematically investigated the influence of cell shape on physical straining. In an evaluation of the transport behavior of 14 different bacterial strains in porous media, Weiss et al [142] observed preferential removal of long, rod-shaped cells. Because of the small bacteria to grain diameter ratio $\left(d_{\mathrm{p}} / d_{\mathrm{c}} \approx 0.0014\right)$, these researchers did not consider straining to be an important removal mechanism in their experiments.

Although straining has been shown to influence microbe removal rates under certain conditions, it is not considered in most existing modeling approaches. The numerical simulations of Bradford et al $[16,17]$ illustrate how classical colloid filtration theory - which does not consider removal by straining — is not always appropriate for describing particle (microbe) transport in porous media. Particularly, in settings such as bank filtration where straining is expected to be a dominant removal mechanism for relatively large pathogenic protozoa (e.g., Cryptosporidium or Cyclospora), CFT cannot be used to estimate (oo)cyst travel distances.

\subsection{Microbial growth and inactivation are difficult to predict}

In mathematical models of microbial transport and fate, the processes of microbial growth and inactivation (or death) are described as source and sink terms, respectively. These mechanisms may be relevant for both suspended (fluid-phase) and attached microorganisms, and are typically represented using first-order rate expressions [32,114]. In general though, these mechanisms are not well understood within the context of microbial transport in porous media.

The Monod relationship can be used to describe bacterial growth in transport models, however its relevance to subsurface environments has not been demonstrated $[32,55]$. A difficulty 
associated with this approach is determining the values of the Monod parameters, namely, the maximum growth rate and the affinity constant. These microbe-specific "constants" are sensitive to changes in environmental conditions and substrate. Moreover, it is not easy to obtain accurate estimates of these parameters for in-situ conditions because of the difficulty in obtaining uncontaminated samples and accounting for temporal and spatial variations in microbial activity. The development and use of sophisticated imaging devices and flow chambers is likely to facilitate predictions of microbial growth rates in porous media [43, 147].

Survival of microorganisms in saturated porous media is affected by many factors, including the type of microbe, the presence of predators and parasites, pore water composition and temperature, and degree of attachment $[55,148]$. Interaction amongst these factors is also probable and presents an additional challenge when predicting the role of inactivation (or death) in microbe transport. A substantial research effort has been directed at elucidating the influence of various environmental factors on the inactivation of viruses [61, 111, 114, 115, 148]. These studies demonstrate how difficult it is to draw any general conclusions on the role of certain factors in virus inactivation. For instance, the effect of attachment on the rate of virus inactivation is not clear - attachment to some geological media accelerates inactivation, whereas attachment to other mineral surfaces may protect viruses from inactivation $[61,111,114]$. Similarly, there have been contradictory reports regarding the influence of other microorganisms, such as bacteria, on virus inactivation [148]. Some studies have shown that viruses persist longer under sterile conditions, whereas the opposite effect has also been observed [148].

This observed variability in microbial growth and inactivation processes suggests that incorporation of these mechanisms into predictive models of microbial transport should be treated on a case-by-case basis. 


\subsection{Detachment of microorganisms is often overlooked}

The release (detachment) of microorganisms from sediment grain surfaces can be of considerable importance in natural subsurface environments and engineered water treatment systems. Specifically, detachment of pathogenic microbes (e.g., C. parvum) from granular media can pose a significant risk to drinking water safety [50,149]. Detachment of bacteria is also undesirable during in-situ bioremediation efforts, where the objective is to maintain a critical microbial mass at a specific location.

Unprompted release of microorganisms has been observed in laboratory and field-scale transport experiments involving bacteria, viruses and protozoa $[5,46,54,63,64,84,116,149]$. In such studies, observations of "tailing" in measured breakthrough curves are attributed to microbial detachment, whereby an excessively long tail is indicative of very slow release $[5,114,149]$. Slow release of attached microbes over extended time periods may contribute significantly to longdistance transport, however few field-scale studies have actually monitored long-term changes in microbial concentration $[58,116,149]$. Zhang et al [149] observed extended tailing of bacteria at the South Oyster, VA site over a period of four months. In this study, microbial attachment and detachment rates were estimated by fitting a one-dimensional transport model (eqs 3 and 4 ) to the measured concentrations of suspended bacteria. Numerical simulations using the resulting model parameters revealed that detachment could substantially increase bacteria travel distances.

Although the occurrence of microbial detachment has been noted in several experimental investigations, it is often overlooked in efforts to model microbe transport behavior. For instance, detachment is not considered in the classical colloid filtration theory (eq 5), which is the most commonly used approach for predicting microbe migration and fate in saturated porous media [50, 
146]. One explanation for this oversight is the deficiency in our current understanding of microbial detachment processes. Several physical, chemical and biological factors may influence the rate and extent of microbial detachment from sediment grain surfaces. For example, some studies indicate that a microorganism's detachment behavior may be linked to nutrient availability [50, $67,92]$. Others suggest that hydrodynamic shear and/or collisions with suspended particles may affect the degree of microbe release $[50,71,80]$. Research also shows that detachment may be a function of microbial residence time on the collector surface $[69,88]$. In this case, the detachment process is described using a distribution in detachment rates. An improved understanding of these and other factors controlling microbial release is required before practical incorporation of this process into mathematical transport models.

\section{Proposed Improvements to the Classical Filtration Theory}

In the previous section, several issues were raised concerning current methods used to model microbe transport and fate in saturated porous media. Research suggests that the equilibrium sorption mechanism is not appropriate for describing microbial attachment under most conditions. The effects of microbe-specific surface features, physical straining, detachment, growth and inactivation are not well understood and therefore rarely considered in microbe transport models. As a consequence, the most widely used approach for evaluating microbial transport behavior has been the most simple; namely, colloid filtration theory. However, as indicated previously, there are many limitations related to the application of CFT. In light of these concerns, certain modifications to classical CFT have recently been proposed.

\subsection{A distribution in particle deposition rates}


An experimental investigation carried out by Albinger et al [3] was one of the first to show that predictions of colloid transport based on CFT were not in good agreement with laboratory observations. These researchers found that a broad range of adhesion affinities $(\alpha)$ was required to account for the observed filtration behavior of a monoclonal bacterial population. Other investigators have since suggested a number of different distribution functions (e.g., power-law, bimodal, and lognormal) to describe the measured profiles of retained microorganisms [10, 100, 135]. In these studies, it was proposed that a distribution in microbial deposition rates could arise from, amongst others, variations in microbial surface properties. More recent experiments conducted with model latex colloids in columns packed with glass beads (see section 3.2) indicate that distributions in particle-collector interaction energies could be the major cause of the observed breakdown of CFT [77, 130, 132]. Specifically, it has been shown that under generally unfavorable conditions for deposition, three different types of particle-collector interactions may occur: (i) particles may overcome a repulsive energy barrier to deposit in the primary energy well, (ii) particles may encounter a deep secondary energy well where they can be retained, and (iii) the presence of surface charge heterogeneities may provide opportunities for particle deposition in the primary energy well in the absence of an energy barrier [130, 132]. As described previously, these different attachment mechanisms can give rise to both "slow" and "fast" particle or microbe deposition rates in porous media. This variation in deposition rates - which is driven by the presence of particle/microbe heterogeneity - can be incorporated into CFT by considering a bimodal distribution in $k_{\text {att }}$ [132]. Indeed, model predictions obtained using a proposed dual deposition mode (DDM) model were shown to be in good agreement with independent sets of experimental data obtained with model (latex) colloids [132] as well as biocolloids (e.g., oocysts of Cryptosporidium parvum) [133]. These findings suggest that modification of CFT to include a 
bimodal distribution in deposition rates should be a valuable change with respect to improvement of the classical model.

\subsection{Straining as a removal mechanism}

Microbe removal by straining is generally considered irreversible and can be described mathematically using a depth-dependent first-order expression. Bradford et al [17] used such an approach to simulate the effects of straining on particle transport whereby they included a depthdependent removal term in eq 4 . That is, these researchers considered the general form of the microbial transport model (eqs 2 and 4) where they took into account the effects of physicochemical filtration $\left(k_{\mathrm{att}}\right)$, detachment $\left(k_{\mathrm{det}}\right)$, and straining. Results of their work indicate that a more realistic representation of the experimental data is obtained when the removal of particles by both attachment and straining are considered. The modeling approach implemented by Bradford et al [17] can readily be applied to extend classical CFT to include the effects of physical straining (in the absence of detachment):

$$
\frac{\rho_{b}}{\varepsilon} \frac{\partial S}{\partial t}=k_{\mathrm{att}} C-k_{\mathrm{str}} \psi_{\mathrm{str}} C
$$

where $k_{\text {str }}$ is the straining coefficient and $\psi_{\text {str }}$ is a dimensionless depth-dependent straining function. The straining function may take a wide range of forms, but the following power-law function has been shown useful [17]:

$$
\psi_{\mathrm{str}}=\left(\frac{d_{c}+x}{d_{c}}\right)^{-\beta}
$$

Here, $\beta$ is a fitting parameter that controls the shape of the spatial distribution of retained colloids. When eqs 2 and 8 are combined and solved within the context of CFT, (i.e., steady-state 
conditions and negligible dispersion effects), the resulting model can be used to interpret microbe transport behavior under the influence of straining and attachment.

\subsection{Accounting for microbe mobility}

Propelled by their flagella, motile bacteria swim in the direction of their long axis at a rate of approximately 35 diameters/s [12]. Certain motile cells are capable of sensing chemical gradients and moving towards more favorable conditions. These chemotactic bacteria may exhibit different transport behavior from their non-motile counterparts [26, 85], however well-controlled studies on the role of motility in porous media transport are scarce.

Barton and Ford [9] proposed a simple mathematical model which characterizes the transport of motile bacteria through porous media using two effective transport parameters random motility and chemotactic sensitivity. Comparison of model calculations with previously published experimental data showed that the presence of the porous medium caused a reduction in the random motility of the microbe population consistent with theoretical predictions. Duffy et al [42] used cellular dynamics simulations (CDS) to examine the effect of local chemical gradients on chemotactic behavior in porous media. Results of their simulations indicate that chemotaxis may increase bacterial migration in response to microscale gradients and can also enhance bacterial residence time near a nutrient source. Although the models of Barton and Ford [9] and Duffy et al [42] provide useful insight on the role of motility in bacteria transport, the effect of fluid flow is neglected in these approaches.

More recently, Nelson and Ginn [89] developed a mathematical model of microbial transport which considers the influences of (i) cell motility, (ii) physicochemical interactions between microbes and collector surfaces, and (iii) convective flow. By integrating CDS with 
particle trajectory analysis, these researchers calculate the value of the single-collector contact efficiency, $\eta_{0}$, with the effects of chemotaxis incorporated. Preliminary results suggest that, under certain conditions, chemotaxis may cause a change in the dependence of $\eta_{0}$ on porewater velocity [89]. However, it is important to note that this model does not consider the influences of sedimentation, hydrodynamic (viscous) interactions, and Brownian diffusion on microbial attachment. The two latter mechanisms can be significant for particles as large as a few micrometers for transport at low Peclet numbers or flow rates (such as in subsurface environments), thus including a broad range of motile microorganisms of environmental relevance [131].

\section{Concluding Remarks}

In an effort to develop improved models of microbial transport in natural and engineered systems, the factors controlling migration and removal of microbes in porous media have been studied extensively. Based on these studies, a number of different mathematical approaches have been proposed to model microbial behavior observed in traditional packed column experiments or field-scale investigations. Several of these modeling approaches have inherent weaknesses or inconsistencies which are often overlooked by users. For instance, the relevance of classical colloid filtration theory seems to be limited to mainly favorable deposition conditions in ideal systems. In certain cases, models of microbial transport have been modified to account for these limitations (e.g., several researchers propose that a distribution in deposition rates should be incorporated into CFT). Such adjustments to traditional modeling approaches should provide significant improvements to predictions of microbial transport in porous media. However, a great deal more research is necessary to develop a comprehensive model of microbial migration which 
considers the wide range of transport and deposition behavior encountered in complex natural environments.

Future areas for fundamental research in this area have been identified and include: (i) inactivation kinetics of pathogens in soils, (ii) role of protozoan grazing in removal of bacteria, (iii) mechanisms of microbial detachment from sediment grain surfaces, (iv) interactions between cell/cyst surface biomolecules and mineral surfaces, and (v) the influence of physical and geochemical aquifer heterogeneity on microbial transport $[45,50,126]$. Ginn et al [50] indicate how biological processes may be affected by one another and it may be necessary to consider the interdependency of such processes in the development of new models. There may also not be a clear distinction between mechanisms that are typically considered physicochemical and those that are biological because these processes are often coupled in relation to microbial transport and deposition [50]. Additional well-controlled laboratory-scale studies could improve our fundamental understanding of these mechanisms and allow the design of more accurate and complete models of microbial transport in porous media.

\section{Acknowledgements}

The author acknowledges the support of the Brace Centre for Water Resources Management at McGill University and the Canada Research Chairs Program.

\section{Notation}

\section{Symbols}

C aqueous phase (suspended) microbe concentration

$C_{0} \quad$ bulk (influent) microbe concentration

D hydrodynamic dispersion coefficient 


$\begin{array}{ll}d_{10} & \begin{array}{l}\text { grain diameter for which } 10 \% \text { of all particles in the volume distribution are } \\ \text { smaller }\end{array} \\ d_{\mathrm{a}} & \begin{array}{l}\text { arithmetic mean diameter of collector (sand grain) } \\ d_{\mathrm{c}}\end{array} \\ d_{\mathrm{g}} & \text { diameter of spherical collector } \\ d_{\mathrm{p}} & \text { geometric mean diameter of collector (sand grain) } \\ K_{e q} & \text { diameter of particle } \\ k_{\mathrm{att}} & \text { equilibrium distribution coefficient } \\ k_{\mathrm{det}} & \text { microbial attachment rate coefficient } \\ k_{\mathrm{str}} & \text { microbial detachment rate coefficient } \\ N_{\mathrm{Pe}} & \text { microbial straining coefficient } \\ R & \text { Peclet number; } N_{\mathrm{Pe}}=v x / D \\ S & \text { retardation factor, } R=1+\rho_{\mathrm{b}} K_{\mathrm{eq}} / \varepsilon \\ T & \text { attached microbe concentration } \\ t & \text { absolute temperature } \\ t_{0} & \text { time } \\ U & \text { duration of microbe injection } \\ v & \text { approach (superficial) velocity of fluid } \\ x & \text { interstitial pore velocity; } v=U / \varepsilon\end{array}$

\section{Greek Symbols}

$\begin{array}{ll}\alpha & \text { microbe attachment (collision) efficiency } \\ \beta & \text { fitting parameter for straining function } \\ \varepsilon & \text { porosity of a porous medium } \\ \eta_{0} & \text { overall single-collector contact efficiency } \\ \rho_{\mathrm{b}} & \text { dry bulk density of porous medium } \\ \psi_{\mathrm{str}} & \text { dimensionless depth-dependent straining function }\end{array}$




\section{References}

[1] Abudalo R. A., Bogatsu Y. G., Ryan J. N., Harvey R. W., Metge D. W. and Elimelech M. Effect of Ferric Oxyhydroxide Grain Coatings on the Transport of Bacteriophage PRD1 and Cryptosporidium parvum Oocysts in Saturated Porous Media. Environ. Sci. Technol. 2005;39:6412-6419.

[2] Abu-Lail N. I. and Camesano T. A. The Role of Lipopolysaccharides in the Adhesion, Retention, and Transport of Escherichia coli JM109. Environ. Sci. Technol. 2003;37:2173-2183.

[3] Albinger O., Biesemeyer B. K., Arnold R. G. and Logan B. E. Effect of Bacterial Heterogeneity on Adhesion to Uniform Collectors by Monoclonal Populations. Fems Microbiol Lett 1994;124:321-326.

[4] Bales R. C., Gerba C. P., Grondin G. H. and Jensen S. L. Bacteriophage transport in sandy soil and fractured tuff. Appl. Environ. Microbiol. 1989;55:2061-2067.

[5] Bales R. C., Hinkle S. R., Kroeger T. W. and Stocking K. Bacteriophage adsorption during transport through porous media: chemical perturbations and reversibility. Environ. Sci. Technol. 1991;25:2088-2095.

[6] Bales R. C., Li S., Maguire K. M., Yahya M. T. and Gerba C. P. MS-2 and poliovirus transport in porous media: hydrophobic effects and chemical perturbations. Water Resour. Res. 1993;29:957-963.

[7] Bales R. C., Li S., Maguire K. M., Yahya M. T., Gerba C. P. and Harvey R. W. Virus and bacteria transport in a sandy aquifer, Cape Cod, MA. Ground Water 1995;33:653-661.

[8] Bales R. C., Li S., Yeh T.-C. J., Lenczewski M. E. and Gerba C. P. Bacteriophage and microsphere transport in saturated porous media: forced-gradient experiment at Borden, Ontario. Water Resour. Res. 1997;33:639-648.

[9] Barton J. W. and Ford R. M. Mathematical model for characterization of bacterial migration through sand cores. Biotechnology and Bioengineering 1997;53:487-496.

[10] Baygents J. C., Glynn J. R., Albinger O., Biesemeyer B. K., Ogden K. L. and Arnold R. G. Variation of surface charge density in monoclonal bacterial populations: Implications for transport through porous media. Environ. Sci. Technol. 1998;32:1596-1603.

[11] Becker M. W., Collins S. A., Metge D. W., Harvey R. W. and Shapiro A. M. Effect of cell physicochemical characteristics and motility on bacterial transport in groundwater. J. Contam. Hydrol. 2004;69:195-213.

[12] Berg H. C. Motile behavior of bacteria. Physics Today 2000;53:24-29.

[13] Bolster C. H., Mills A. L., Hornberger G. and Herman J. Effect of surface coatings, grain size, and ionic strength on the maximum attainable coverage of bacteria on sand surfaces. J. Contam. Hydrol. 2001;50:287-305.

[14] Bolster C. H., Mills A. L., Hornberger G. M. and Herman J. S. Spatial distribution of deposited bacteria following miscible displacement experiments in intact cores. Water Resour. Res. 1999;35:1797-1807.

[15] Bos R., van der Mei H. C. and Busscher H. J. Physico-chemistry of initial microbial adhesive interactions - its mechanisms and methods for study. Fems Microbiol Rev 1999;23:179-230.

[16] Bradford S. A., Bettahar M., Simunek J. and van Genuchten M. T. Straining and attachment of colloids in physically heterogeneous porous media. Vadose Zone Journal 2004;3:384-394.

[17] Bradford S. A., Simunek J., Bettahar M., van Genuchten M. T. and Yates S. R. Modeling colloid attachment, straining, and exclusion in saturated porous media. Environ. Sci. Technol. 2003;37:2242-2250.

[18] Bradford S. A., Yates S. R., Bettahar M. and Simunek J. Physical factors affecting the transport and fate of colloids in saturated porous media. Water Resour. Res. 2002;38:1327-1338.

[19] Brown D. G. and Jaffe P. R. Effects of nonionic surfactants on bacterial transport through porous media. Environ. Sci. Technol. 2001;35:3877-3883.

[20] Brown D. G., Stencel J. R. and Jaffe P. R. Effects of porous media preparation on bacteria transport through laboratory columns. Water Res. 2002;36:105-114.

[21] Brush C. F., Ghiorse W. C., Anguish L. J., Parlange J. Y. and Grimes H. G. Transport of Cryptosporidium parvum oocysts through saturated columns. J. Environ. Qual. 1999;28:809-815.

[22] Burks G. A., Velegol S. B., Paramonova E., Lindenmuth B. E., Feick J. D. and Logan B. E. Macroscopic and Nanoscale Measurements of the Adhesion of Bacteria with Varying Outer Layer Surface Composition. Langmuir 2003; 19:2366-2371.

[23] Camesano T. A. and Abu-Lail N. I. Heterogeneity in Bacterial Surface Polysaccharides, Probed on a SingleMolecule Basis. Biomacromolecules 2002;3:661-667.

[24] Camesano T. A. and Logan B. E. Influence of Fluid Velocity and Cell Concentration on the Transport of Motile and Nonmotile Bacteria in Porous Media. Environ. Sci. Technol. 1998;32:1699-1708.

[25] Camesano T. A., Unice K. M. and Logan B. E. Blocking and ripening of colloids in porous media and their implications for bacterial transport. Colloid Surf. A: Physicochem. Eng. Asp. 1999;160:291-308. 
[26] Camper A. K., Hayes J. T., Sturman P. J., Jones W. L. and Cunningham A. B. Effects of motility and adsorption rate coefficient on transport of bacteria through saturated porous media. Appl. Environ. Microbiol. 1993;59:34553462 .

[27] Chen G. and Strevett K. Surface free energy relationships used to evaluate microbial transport. Journal of Environmental Engineering 2002;128:408-415.

[28] Chu Y., Jin Y. and Yates M. V. Virus transport through saturated sand columns as affected by different buffer solutions. J. Environ. Qual. 2000;29:1103-1110.

[29] Considine R. F., Dixon D. R. and Drummond C. J. Laterally-Resolved Force Microscopy of Biological Microspheres - Oocysts of Cryptosporidium parvum. Langmuir 2000;16:1323-1330.

[30] Considine R. F., Dixon D. R. and Drummond C. J. Oocysts of Cryptosporidium parvum and model sand surfaces in aqueous solutions: an atomic force microscope (AFM) study. Water Res. 2002;36:3421-3428.

[31] Considine R. F., Drummond C. J. and Dixon D. R. Force of Interaction between a Biocolloid and an Inorganic Oxide: Complexity of Surface Deformation, Roughness, and Brushlike Behavior. Langmuir 2001;17:6325-6335.

[32] Corapcioglu M. Y. and Haridas A. Microbial transport in soils and groundwater: a numerical model. Advances in Water Resources 1985;8:188-200.

[33] Dai X. and Hozalski R. M. Evaluation of Microspheres as Surrogates for Cryptosporidium parvum Oocysts in Filtration Experiments. Environ. Sci. Technol. 2003;37:1037-1042.

[34] DeBorde D. C., Woessner W. W., Kiley Q. T. and Ball P. N. Rapid transport of viruses in a floodplain aquifer. Water Res. 1999;33:2229-2238.

[35] DeFlaun M. F., Oppenheimer S. R., Streger S., Condee C. W. and Fletcher M. Alterations in adhesion, transport, and membrane characteristics in an adhesion-deficient pseudomonad. Appl. Environ. Microbiol. 1999;65:759-765.

[36] Derjaguin B. V. and Landau L. D. Theory of the stability of strongly charged lyophobic sols and of the adhesion of strongly charged particles in solutions of electrolytes. Acta Physicochim. URSS 1941;14:733-762.

[37] Deshpande P. A. and Shonnard D. R. An improved spectrophotometric method to study the transport, attachment, and breakthrough of bacteria through porous media. Appl. Environ. Microbiol. 2000;66:763-768.

[38] Dong H., Onstott T. C., DeFlaun M. F., Fuller M. E., Scheibe T. D., Streger S. H., Rothmel R. K. and Mailloux B. J. Relative dominance of physical versus chemical effects on the transport of adhesion-deficient bacteria in intact cores from South Oyster, Virginia. Environ. Sci. Technol. 2002;36:891-900.

[39] Dong H., Onstott T. C., Ko C. H., Hollingsworth A. D., Brown D. G. and Mailloux B. J. Theoretical prediction of collision efficiency between adhesion-deficient bacteria and sediment grain surface. Colloid Surface B 2002;24:229-245.

[40] Dong H., Rothmel R., Onstott T. C., Fuller M. E., DeFlaun M. F., Streger S. H., Dunlap R. and Fletcher M. Simultaneous transport of two bacterial strains in intact cores from Oyster, Virginia: Biological effects and numerical modeling. Appl. Environ. Microbiol. 2002;68:2120-2132.

[41] Dowd D. E., Pillai S. D., Wang S. and Corapcioglu M. Y. Delineating the specific influence of virus isoelectric point and size on virus adsorption and transport through sandy soils. Appl. Environ. Microbiol. 1998;64:405-410.

[42] Duffy K. J., Ford R. M. and Cummings P. T. Residence time calculation for chemotactic bacteria within porous media. Biophysical Journal 1997;73:2930-2936.

[43] Dupin H. J. and McCarty P. L. Mesoscale and microscale observations of biological growth in a silicon pore imaging element. Environ. Sci. Technol. 1999;33:1230-1236.

[44] Elimelech M., Gregory J., Jia X. and Williams R. A. Particle Deposition and Aggregation: Measurement, Modelling, and Simulation. Butterworth-Heinemann: Oxford, England, 1995.

[45] Ferguson C., de Roda Husman A. M., Altavilla N., Deere D. and Ashbolt N. Fate and transport of surface water pathogens in watersheds. Crit. Rev. Environ. Sci. Technol. 2003;33:299-361.

[46] Fontes D. E., Mills A. L., Hornberger G. and Herman J. S. Physical and chemical factors influencing transport of microorganisms through porous media. Appl. Environ. Microbiol. 1991;57:2473-2481.

[47] Foppen J. W. A. and Schijven J. F. Transport of E. coli in columns of geochemically heterogeneous sediment. Water Res. 2005;39:3082-3088.

[48] Franchi A. and O'Melia C. R. Effects of Natural Organic Matter and Solution Chemistry on the Deposition and Reentrainment of Colloids in Porous Media. Environ. Sci. Technol. 2003;37:1122-1129.

[49] Gannon J., Tan Y., Baveye P. and Alexander M. Effect of sodium chloride on transport of bacteria in a saturated aquifer material. Appl. Environ. Microbiol. 1991;57:2497-2501.

[50] Ginn T. R., Wood B. D., Nelson K. E., Scheibe T. D., Murphy E. M. and Clement T. P. Processes in microbial transport in the natural subsurface. Advances in Water Resources 2002;25:1017-1042.

[51] Hahn M. W. Ph.D. Dissertation, The Johns Hopkins University, 1994. 
[52] Hahn M. W., Abadzic D. and O'Melia C. R. Aquasols: On the Role of Secondary Minima. Environ. Sci. Technol. 2004;38:5915-5924.

[53] Hahn M. W. and O'Melia C. R. Deposition and Reentrainment of Brownian Particles in Porous Media under Unfavorable Chemical Conditions: Some Concepts and Applications. Environ. Sci. Technol. 2004;38:210-220.

[54] Harter T., Wagner S. and Atwill E. R. Colloid transport and filtration of Cryptosporidium parvum in sandy soils and aquifer sediments. Environ. Sci. Technol. 2000;34:62-70.

[55] Harvey R. W. Parameters involved in modeling movement of bacteria in groundwater. In: C. J. Hurst, Modeling the Environmental Fate of Microorganisms: Washington, D. C., American Society for Microbiology, pp.89-114.

[56] Harvey R. W. and Garabedian S. P. Use of Colloid Filtration Theory in Modeling Movement of Bacteria through a Contaminated Sandy Aquifer. Environ. Sci. Technol. 1991;25:178-185.

[57] Harvey R. W. and Harms H. Transport of Microorganisms in the Terrestrial Subsurface: In Situ and Laboratory Methods. In: C. J. Hurst, Manual of Environmental Microbiology: Washington, D.C., ASM Press, pp.1138.

[58] Harvey R. W., Kinner N. E., Bunn A., MacDonald D. and Metge D. W. Transport behavior of groundwater protozoa and protozoan-sized microspheres in sandy aquifer sediments. Appl. Environ. Microbiol. 1995;61:209-217. [59] Harvey R. W., Kinner N. E., MacDonald D., Metge D. W. and Bunn A. Role of physical heterogeneity in the interpretation of small-scale laboratory and field observations on bacteria, microbial-sized microsphere, and bromide transport through aquifer sediments. Water Resour. Res. 1993;29:2713-2721.

[60] Harvey R. W., Mayberry N., Kinner N. E., Metge D. W. and Novarino F. Effect of growth conditions and staining procedure upon the subsurface transport and attachment behaviors of a groundwater protist. Appl. Environ. Microbiol. 2002;68:1872-1881.

[61] Harvey R. W. and Ryan J. N. Use of PRD1 bacteriophage in groundwater viral transport, inactivation, and attachment studies. FEMS Microbiology Ecology 2004;49:3-16.

[62] Hendry M. J., Lawrence J. R. and Maloszewski P. Effects of velocity on the transport of two bacteria through saturated sand. Ground Water 1999;37:103-113.

[63] Hendry M. J., Lawrence J. R. and Maloszewski P. The role of sorption in the transport of Klebsiella oxytoca through saturated silica sand. Ground Water 1997;35:574-584.

[64] Hornberger G. M., Mills A. L. and Herman J. S. Bacterial transport in porous media: evaluation of a model using laboratory observations. Water Resour. Res. 1992;28:915-938.

[65] Hsu B.-M., Huang C. P. and Pan J. R. Filtration behaviors of Giardia and Cryptosporidium - Ionic strength and pH effects. Water Res. 2001;35:3777-3782.

[66] Hubbard S. S., Chen J., Peterson J., Majer E. L., Williams K. H., Swift D. J., Mailloux B. J. and Rubin Y. Hydrogeological characterization of the South Oyster Bacterial Transport Site using geophysical data. Water Resour. Res. 2001;37:2431-2456.

[67] Hunt S. M., Werner E. M., Huang B., Hamilton M. A. and Stewart P. S. Hypothesis for the role of nutrient starvation in biofilm detachment. Appl. Environ. Microbiol. 2004;70:7418-7425.

[68] Jin Y., Yates M. V., Thompson S. S. and Jury W. A. Sorption of viruses during flow through saturated sand columns. Environ. Sci. Technol. 1997;31:548-555.

[69] Johnson W. P., Blue K. A., Logan B. E. and Arnold R. G. Modeling bacterial detachment during transport through porous media as a residence-time-dependent process. Water Resour. Res. 1995;31:2649-2658.

[70] Johnson W. P., Zhang P., Fuller M. E., Scheibe T. D., Mailloux B. J., Onstott T. C., DeFlaun M. F., Hubbard S. S., Radtke J., Kovacik W. P. and Holben W. E. Ferrographic tracking of bacterial transport in the field at the Narrow Channel Focus Area, Oyster, VA. Environ. Sci. Technol. 2001;35:182-191.

[71] Johnson W. P., Zhang P., Gardner P. M., Fuller M. E. and DeFlaun M. F. Evidence for Detachment of Indigenous Bacteria from Aquifer Sediment in Response to Arrival of Injected Bacteria. Appl. Environ. Microbiol. 2001;67:49084913.

[72] Kinoshita T., Bales R. C., Maguire K. M. and Gerba C. P. Effect of pH on bacteriophage transport through sandy soils. J. Contam. Hydrol. 1993;14:55-70.

[73] Kuznar Z. A. and Elimelech M. Adhesion kinetics of viable Cryptosporidium parvum oocysts to quartz surfaces. Environ. Sci. Technol. 2004;38:6839-6845.

[74] Kuznar Z. A. and Elimelech M. Role of surface proteins in the deposition kinetics of Cryptosporidium parvum oocysts. Langmuir 2005;21:710-716.

[75] Lance J. C. and Gerba C. P. Effect of ionic composition of suspending solution on virus adsorption by a soil column. Appl. Environ. Microbiol. 1984;47:484-488.

[76] Li X. and Johnson W. P. Nonmonotonic variations in deposition rate coefficients of microspheres in porous media under unfavorable deposition conditions. Environ. Sci. Technol. 39:1658-1665. 
[77] Li X., Scheibe T. D. and Johnson W. P. Apparent Decreases in Colloid Deposition Rate Coefficients with Distance of Transport under Unfavorable Deposition Conditions: A General Phenomenon. Environ. Sci. Technol. 2004;38:5616-5625.

[78] Martin M. J., Logan B. E., Johnson W. P., Jewett D. G. and Arnold R. G. Scaling bacterial filtration rates in different sized porous media. J. Environ. Eng.-ASCE 1996;122:407-415.

[79] Martin R. E., Bouwer E. J. and Hanna L. M. Application of Clean-Bed Filtration Theory to Bacterial Deposition in Porous-Media. Environ. Sci. Technol. 1992;26:1053-1058.

[80] Mascari L., Ymele-Leki P., Eggleton C. D., Speziale P. and Ross J. M. Fluid shear contributions to bacteria cell detachment initiated by a monoclonal antibody. Biotechnology and Bioengineering 2003;83:65-74.

[81] Mawdsley J. L., Bardgett R. D., Merry R. J., Pain B. F. and Theodorou M. K. Pathogens in Livestock Waste, Their Potential for Movement through Soil and Environmental-Pollution. Appl. Soil Ecol. 1995;2:1-15.

[82] Mawdsley J. L., Brooks A. E. and Merry R. J. Movement of the protozoan pathogen Cryptosporidium parvum through three contrasting soil types. Biol. Fertil. Soils 1996;21:30-36.

[83] McCaulou D. R., Bales R. C. and Arnold R. G. Effect of temperature-controlled motility on transport of bacteria and microspheres through saturated sediment. Water Resour. Res. 1995;31:271-280.

[84] McCaulou D. R., Bales R. C. and McCarthy J. F. Use of Short-Pulse Experiments to Study Bacteria Transport through Porous-Media. J. Contam. Hydrol. 1994;15:1-14.

[85] McClaine J. W. and Ford R. M. Characterizing the adhesion of motile and nonmotile Escherichia coli to a glass surface using a parallel-plate flow chamber. Biotechnology and Bioengineering 2002;78:179-189.

[86] McKay L. D., Cherry J. A., Bales R. C., Yahya M. T. and Gerba C. P. A field example of bacteriophage as tracers of fracture flow. Environ. Sci. Technol. 1993;27:1075-1079.

[87] McKay L. D., Gillham R. W. and Cherry J. A. Field experiments in a fractured clay till 2. solute and colloid transport. Water Resour. Res. 1993;29:3879-3890.

[88] Meinders J. M., van der Mei H. C. and Busscher H. J. Deposition efficiency and reversibility of bacterial adhesion under flow. J. Colloid Interface Sci. 1995;176:329-341.

[89] Nelson K. E. and Ginn T. R. Theoretical investigation of bacterial chemotaxis in porous media. Langmuir 2001;17:5636-5645.

[90] Pang L., Close M., Goltz M., Sinton L., Davies H., Hall C. and Stanton G. Estimation of septic tank setback distances based on transport of E. coli and F-RNA phages. Environment International 2003;29:907-921.

[91] Penrod S. L., Olson T. M. and Grant S. B. Deposition kinetics of two viruses in packed beds of quartz granular media. Langmuir 1996;12:5576-5587.

[92] Peyton B. M. and Characklis W. G. Statistical analysis of the effect of substrate utilization and shear stress on the kinetics of biofilm detachment. Biotechnology and Bioengineering 1993;41:728-735.

[93] Pieper A. P., Ryan J. N., Harvey R. W., Amy G. L., Illangasekare T. H. and Metge D. W. Transport and recovery of bacteriophage PRD1 in a sand and gravel aquifer: effect of sewage-derived organic matter. Environ. Sci. Technol. 1997;31:1163-1170.

[94] Powell K. L., Taylor R. G., Cronin A. A., Barrett M. H., Pedley S., Sellwood J., Trowsdale S. A. and Lerner D. N. Microbial contamination of two urban sandstone aquifers in the UK. Water Res. 2003;37:339-352.

[95] Powelson D. K. and Gerba C. P. Virus removal from sewage effluents during saturated and unsaturated flow through soil columns. Water Res. 1994;28:2175-2181.

[96] Powelson D. K., Gerba C. P. and Yahya M. T. Virus transport and removal in wastewater during aquifer recharge. Water Res. 1993;27:583-590.

[97] Prieve D. C. and Ruckenstein E. Effect of London Forces Upon Rate of Deposition of Brownian Particles. AIChE J 1974;20:1178-1187.

[98] Rajagopalan R. and Tien C. Trajectory Analysis of Deep-Bed Filtration with Sphere-in-Cell Porous-Media Model. AIChE J 1976;22:523-533.

[99] Reddy H. L. and Ford R. M. Analysis of biodegradation and bacterial transport: Comparison of models with kinetic and equilibrium bacterial adsorption. J. Contam. Hydrol. 1996;22:271-287.

[100] Redman J. A., Estes M. K. and Grant S. B. Resolving macroscale and microscale heterogeneity in virus filtration. Colloid Surf. A: Physicochem. Eng. Asp. 2001;191:57-70.

[101] Redman J. A., Grant S. B., Olson T. M. and Estes M. K. Pathogen filtration, heterogeneity, and the potable reuse of wastewater. Environ. Sci. Technol. 2001;35:1798-1805.

[102] Redman J. A., Grant S. B., Olson T. M., Hardy M. E. and Estes M. K. Filtration of recombinant Norwalk virus particles and bacteriophage MS2 in quartz sand: Importance of electrostatic interactions. Environ. Sci. Technol. 1997;31:3378-3383. 
[103] Redman J. A., Walker S. L. and Elimelech M. Bacterial adhesion and transport in porous media: role of the secondary energy minimum. Environ. Sci. Technol. 2004;38:1777-1785.

[104] Rijnaarts H. H. M., Norde W., Bouwer E. J., Lyklema J. and Zehnder A. J. B. Bacterial deposition in porous media related to the clean bed collision efficiency and to substratum blocking by attached cells. Environ. Sci. Technol. 1996;30:2869-2876.

[105] Rijnaarts H. H. M., Norde W., Bouwer E. J., Lyklema J. and Zehnder A. J. B. Bacterial deposition in porous media: Effects of cell-coating, substratum hydrophobicity, and electrolyte concentration. Environ. Sci. Technol. 1996;30:2877-2883.

[106] Rijnaarts H. H. M., Norde W., Bouwer E. J., Lyklema J. and Zehnder A. J. B. Reversibility and mechanism of bacterial adhesion. Colloid Surface B 1995;4:5-22.

[107] Rijnaarts H. H. M., Norde W., Lyklema J. and Zehnder A. J. B. DLVO and steric contributions to bacterial deposition in media of different ionic strengths. Colloid Surface B 1999;14:179-195.

[108] Ruckenstein E. and Prieve D. C. Rate of deposition of Brownian particles under the action of London and double-layer forces. J. Chem. Soc. Faraday Trans. II 1973;69:1522-1536.

[109] Ryan J. N. and Elimelech M. Colloid mobilization and transport in groundwater. Colloid Surf. A 1996;107:156.

[110] Ryan J. N., Elimelech M., Ard R. A., Harvey R. W. and Johnson P. R. Bacteriophage PRD1 and silica colloid transport and recovery in an iron oxide-coated sand aquifer. Environ. Sci. Technol. 1999;33:63-73.

[111] Ryan J. N., Harvey R. W., Metge D. W., Elimelech M., Navigato T. and Pieper A. P. Field and laboratory investigations of inactivation of viruses (PRD1 and MS2) attached to iron oxide-coated quartz sand. Environ. Sci. Technol. 2002;36:2403-2413.

[112] Sakthivadivel R. Clogging of a granular porous medium by sediment. Univ. of Calif., Berkeley, HEL 15-7, $1969,106 \mathrm{p}$.

[113] Sakthivadivel R. Theory and mechanism of filtration of non-colloidal fines through a porous medium. Univ. of Calif., Berkeley, HEL 15-5, 1966, 110 p.

[114] Schijven J. F. and Hassanizadeh S. M. Removal of Viruses by Soil Passage: Overview of Modeling, Processes, and Parameters. Crit. Rev. Environ. Sci. Technol. 2000;30:49-127.

[115] Schijven J. F., Hassanizadeh S. M. and de Bruin H. A. M. Column experiments to study nonlinear removal of bacteriophages by passage through saturated dune sand. J. Contam. Hydrol. 2002;58:243-259.

[116] Schijven J. F., Hoogenboezem W., Hassanizadeh S. M. and Peters J. H. Modeling removal of bacteriophages MS2 and PRD1 by dune recharge at Castricum, Netherlands. Water Resour. Res. 1999;35:1101-1111.

[117] Schijven J. F., Medema G., Vogelaar A. J. and Hassanizadeh S. M. Removal of microorganisms by deep well injection. J. Contam. Hydrol. 2000;44:301-327.

[118] Silliman S. E., Dunlap R., Fletcher M. and Schneegurt M. A. Bacterial transport in heterogeneous porous media: Observations from laboratory experiments. Water Resour. Res. 2001;37:2699-2707.

[119] Simoni S. F., Bosma T. N. P., Harms H. and Zehnder A. J. B. Bivalent Cations Increase Both the Subpopulation of Adhering Bacteria and Their Adhesion Efficiency in Sand Columns. Environ. Sci. Technol. 2000;34:

[120] Simoni S. F., Harms H., Bosma T. N. P. and Zehnder A. J. B. Population heterogeneity affects transport of bacteria through sand columns at low flow rates. Environ. Sci. Technol. 1998;32:2100-2105.

[121] Sinton L., Finlay R. K., Pang L. and Scott D. M. Transport of bacteria and bacteriophages in irrigated effluent into and through an alluvial gravel aquifer. Wat. Air Soil Pollut. 1997;98:17-42.

[122] Smets B. F., Grasso D., Engwall M. A. and Machinist B. D. Surface physicochemical properties of Pseudomonas fluorescens and impact on adhesion and transport through porous media. Colloid Surface B 1999;14:121-139.

[123] Smith J. E. and Perdek J. M. Assessment and management of watershed microbial contaminants. Crit. Rev. Environ. Sci. Technol. 2004;34:109-139.

[124] Spielman L. A. and Friedlander S. K. Role of Electrical Double-Layer in Particle Deposition by Convective Diffusion. J. Colloid Interface Sci. 1974;46:22-31.

[125] Steffan R. J., Sperry K. L., Walsh M. T., Vainberg S. and Condee C. W. Field-Scale Evaluation of In Situ Bioaugmentation for Remediation of Chlorinated Solvents in Groundwater. Environ. Sci. Technol. 1999;33:27712781.

[126] Stevik T. K., Aa K., Ausland G. and Hanssen J. F. Retention and removal of pathogenic bacteria in wastewater percolating through porous media: a review. Water Res. 2004;38:1355-1367.

[127] Tan Y., Gannon J. T., Baveye P. and Alexander M. Transport of bacteria in an aquifer sand: experiments and model simulations. Water Resour. Res. 1994;30:3243-3252.

[128] Tim U. S. and Mostaghimi S. Model for predicting virus movement through soils. Ground Water 1991;29:251259. 
[129] Tong M., Camesano T. A. and Johnson W. P. Spatial Variation in Deposition Rate Coefficients of an AdhesionDeficient Bacterial Strain in Quartz Sand. Environ. Sci. Technol. 2005;39:3679-3687.

[130] Tufenkji N. and Elimelech M. Breakdown of Colloid Filtration Theory: Role of Secondary Energy Minimum and Surface Charge Heterogeneities. Langmuir 2005;21:841-852.

[131] Tufenkji N. and Elimelech M. Correlation Equation for Predicting Single-Collector Efficiency in Physicochemical Filtration in Saturated Porous Media. Environ. Sci. Technol. 2004;38:529-536.

[132] Tufenkji N. and Elimelech M. Deviation from the Classical Colloid Filtration Theory in the Presence of Repulsive DLVO Interactions. Langmuir 2004;20:10818-10828.

[133] Tufenkji N. and Elimelech M. Spatial Distributions of Cryptosporidium Oocysts in Porous Media: Evidence for Dual Mode Deposition. Environ. Sci. Technol. 2005;39:3620-3629.

[134] Tufenkji N., Miller G. F., Ryan J. N., Harvey R. W. and Elimelech M. Transport of Cryptosporidium Oocysts in Porous Media: Role of Straining and Physicochemical Filtration. Environ. Sci. Technol. 2004;38:5932-5938.

[135] Tufenkji N., Redman J. A. and Elimelech M. Interpreting deposition patterns of microbial particles in laboratoryscale column experiments. Environ. Sci. Technol. 2003;37:616-623.

[136] Tufenkji N., Ryan J. N. and Elimelech M. The promise of bank filtration. Environ. Sci. Technol. 2002;36:422a428a.

[137] Unice K. M. and Logan B. E. Insignificant Role of Hydrodynamic Dispersion on Bacterial Transport. Journal of Environmental Engineering 2000;126:491-500.

[138] Van Oss C. J., Good R. J. and Chaudhury M. K. The role of van der Waals forces and hydrogen bonds in 'hydrophobic interactions' between biopolymers and low energy surfaces. J. Colloid Interface Sci. 1986;111:378-390. [139] Verwey E. J. W. and Overbeek J. T. G. Theory of the Stability of Lyophobic Colloids. Elsevier: Amsterdam, 1948.

[140] Walker S. L., Redman J. A. and Elimelech M. Influence of Growth Phase on Bacterial Deposition: Interaction Mechanisms in Packed-Bed Column and Radial Stagnation Point Flow Systems. Environ. Sci. Technol. 2005;39:6405-6411.

[141] Walker S. L., Redman J. A. and Elimelech M. Role of Cell Surface Lipopolysaccharides (LPS) in Escherichia coli K12 Adhesion and Transport. Langmuir 2004;20:7736-7746.

[142] Weiss T. H., Mills A. L., Hornberger G. M. and Herman J. S. Effect of Bacterial Cell Shape on Transport of Bacteria in Porous Media. Environ. Sci. Technol. 1995;29:1737-1740.

[143] West P. A. Human pathogenic viruses and parasites: emerging pathogens in the water cycle. J. Appl. Bacteriol. Suppl. 1991;70:107S-114S.

[144] Williams V. and Fletcher M. Pseudomonas fluorescens adhesion and transport through porous media are affected by lipopolysaccharide composition. Appl. Environ. Microbiol. 1996;62:100-104.

[145] Woessner W. W., Ball P. N., DeBorde D. C. and Troy T. L. Viral transport in a sand and gravel aquifer under field pumping conditions. Ground Water 2001;39:886-894.

[146] Yao K. M., Habibian M. T. and O'Melia C. R. Water and Waste Water Filtration - Concepts and Applications. Environ. Sci. Technol. 1971;5:1105-1112.

[147] Yarwood R. R., Rockhold M. L., Niemet M. R., Selker J. S. and Bottomley P. J. Noninvasive quantitative measurement of bacterial growth in porous media under unsaturated-flow conditions. Appl. Environ. Microbiol. 2002;68:3597-3605.

[148] Yates M. V. and Yates S. R. Modeling microbial fate in the subsurface environment. Critical Reviews in Environmental Control 1988;17:307-344.

[149] Zhang P. F., Johnson W. P., Scheibe T. D., Choi K. H., Dobbs F. C. and Mailloux B. J. Extended tailing of bacteria following breakthrough at the Narrow Channel focus area, Oyster, Virginia. Water Resour. Res. 2001;37:2687-2698. 


\section{Figure Captions}

FIGURE 1. (A) Measured breakthrough of bacteriophage PRD-1 (in $10^{-6} \mathrm{M} \mathrm{Ca}^{2+}$ ) in a column packed with glass beads. Originally presented in ref [5]. (B) Measured breakthrough of bacteriophage MS-2 and $\mathrm{NaCl}$ (tracer) at a field site in the dune area of Castricum, Netherlands (Well 2). Originally presented in ref [116].

FIGURE 2. Comparison of measured retained particle concentration profiles (symbols) and predictions based on classical CFT using $\alpha_{\mathrm{BTC}}$ determined from the corresponding breakthrough curve (dashed lines) for favorable deposition conditions. (A) Deposition of $3 \mu \mathrm{m}$ carboxylmodified latex particles suspended in $300 \mathrm{mM}$ buffered $\mathrm{KCl}$. Originally presented in ref [132]. (B) Deposition of $0.93 \mu \mathrm{m}$ amine-modified latex particles in $1 \mathrm{mM}$ buffered $\mathrm{NaCl}$ (approach velocity $=4 \mathrm{~m} / \mathrm{d}$ ). Originally presented in ref [77]. In both studies, particle deposition was examined using columns packed with glass beads.

FIGURE 3. Comparison of measured retained particle concentration profiles (symbols) and predictions based on classical CFT using $\alpha_{\mathrm{BTC}}$ determined from the corresponding breakthrough curve (dashed lines) for unfavorable deposition conditions. (A) Deposition of carboxyl-modified latex particles suspended in $3 \mathrm{mM}$ buffered $\mathrm{KCl}$. Originally presented in ref [132]. (B) Deposition of carboxyl-modified latex particles in $20 \mathrm{mM}$ buffered $\mathrm{NaCl}$ (approach velocity $=4 \mathrm{~m} / \mathrm{d}$ ). Originally presented in ref [77]. In both studies, particle deposition was examined using columns packed with glass beads.

FIGURE 4. Deposition kinetics of viable, heat treated, and formalin treated Cryptosporidium oocysts onto a quartz surface as a function of solution ionic strength. The deposition kinetics are expressed as oocyst transfer rate coefficient, $k$ RSPF, and attachment efficiency, $\alpha$. The capillary 
flow rate in the RSPF system was fixed at $9.0 \mathrm{~mL} / \mathrm{min}$ (average velocity of $4.77 \mathrm{~cm} / \mathrm{s}$ ). Other experimental conditions were an unadjusted $\mathrm{pH}$ of $5.5-5.7$ and a temperature of $25^{\circ} \mathrm{C}\left( \pm 1^{\circ} \mathrm{C}\right)$. Originally presented in ref [74].

FIGURE 5. Breakthrough curves for experiments conducted with model latex particles of increasing size $(0.32,1.0,1.9$, and $4.1 \mu \mathrm{m})$ suspended in DI water in a column packed with clean quartz sand. Other experimental conditions include approach velocity $=0.042 \mathrm{~cm} / \mathrm{s}$, porosity $=$ 0.43 , mean grain diameter $=0.21 \mathrm{~mm}, \mathrm{pH}=5.6-5.8$, and temperature $=22-23^{\circ} \mathrm{C}$. Originally presented in ref [134]. 

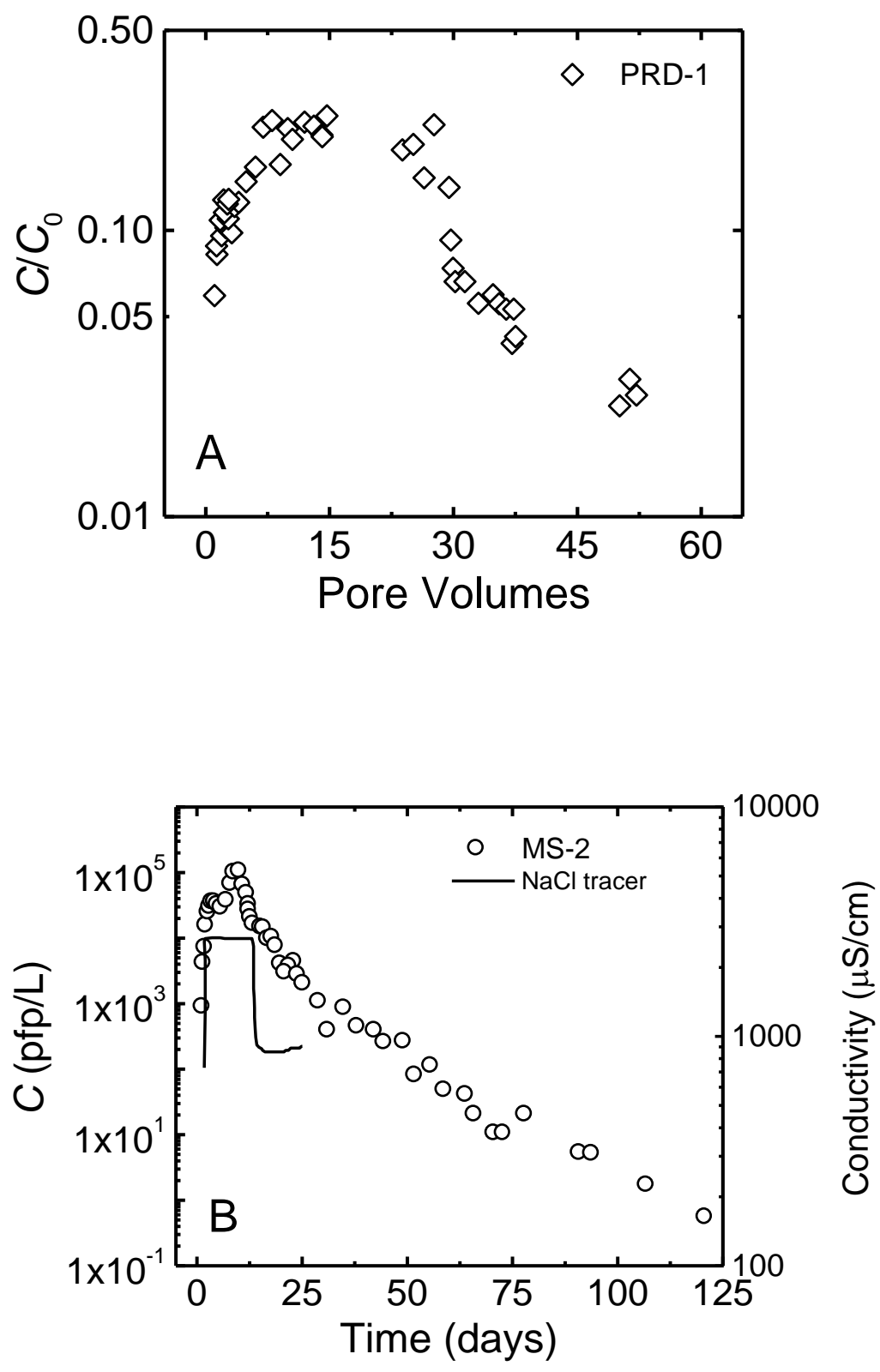

\section{Tufenkji, FIGURE 1}



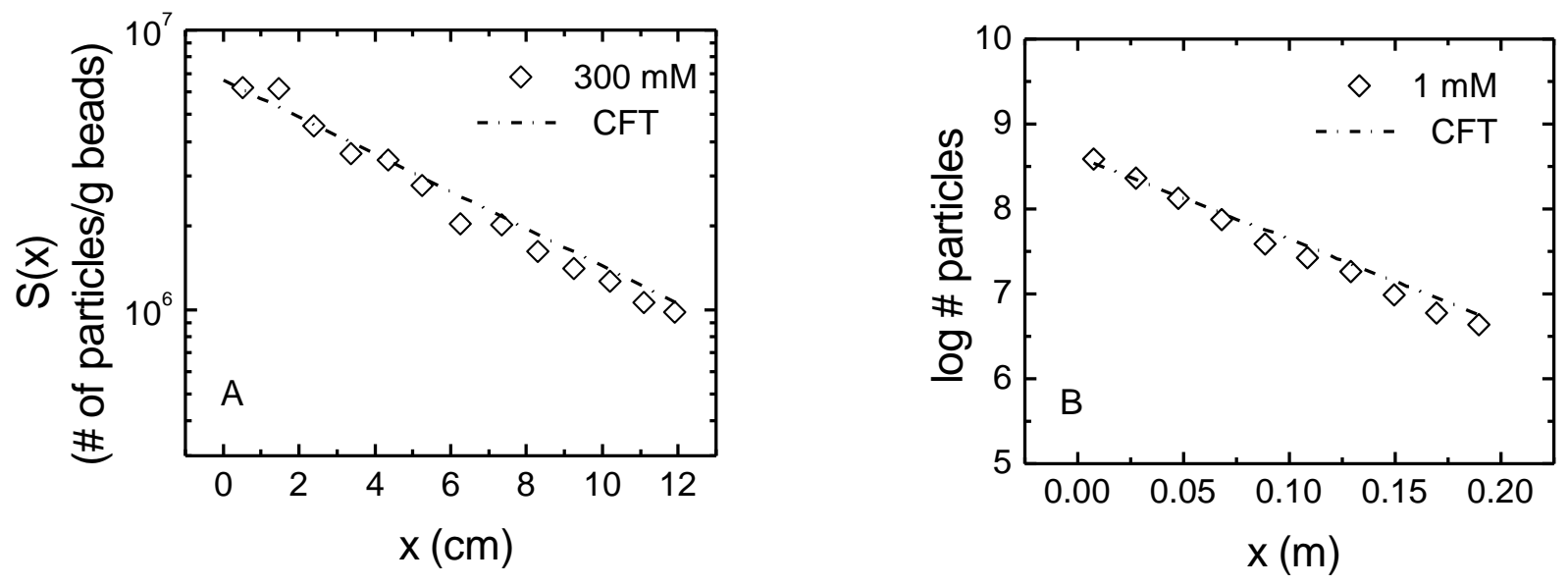

Tufenkji, FIGURE 2
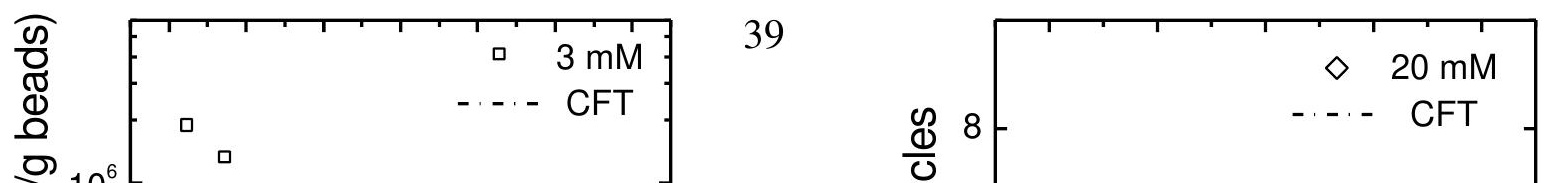


\section{Tufenkji, FIGURE 3}




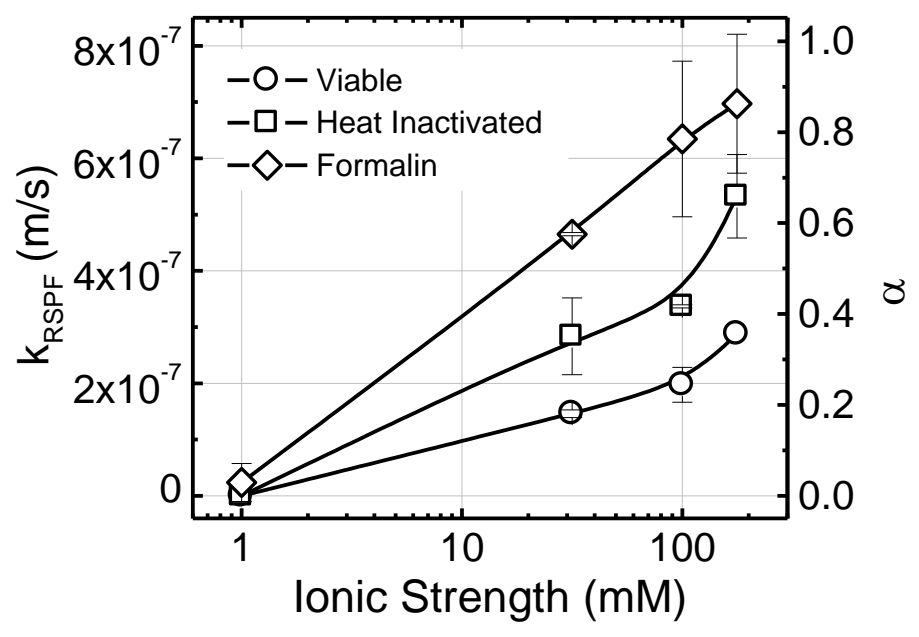

\section{Tufenkji, FIGURE 4}




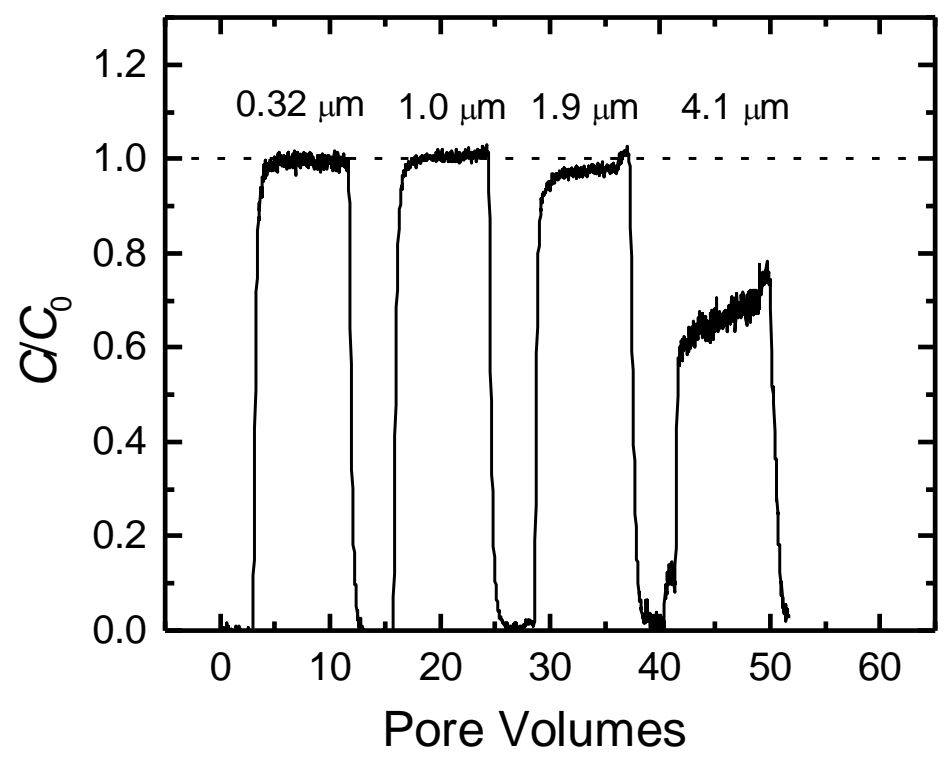

\section{Tufenkji, FIGURE 5}

